\title{
PROVIDING A CONTINUOUS SUPPLY OF TIMBER IN BRITISH COLUMBIA
}

\section{By 1. T. CAMERON ${ }^{1}$}

\section{INTRODUCTION}

The forests, as we all know, are one of our greatest natural assets. We are particularly fortunate in British Columbia. Early in our history, in 1912, our legislators decided to reserve forest lands for the public. Before this the alienation amounted to about 7 per cent, so 93 per cent of the forest lands was retained under government control.

The usual things happened in British Columbia during the next 33 years. The easily accessible forests were overcut. Some of the best forest lands were cleared and became city lots. It is natural for people to learn by others' mistakes and we were the beneficiaries of the mistakes made in various places in the world by people who did not value their forest heritage until too late. Our government, with a gentle nudge from the B.C. Forest Service, saw that something had to be done to save us from the same fate. The problem was to convince the people that it was necessary.

The Forest Service had taken an inventory and based on the standards of the day, it was proven that we had a limited supply of old growth and that without some advanced planning there would be a period of famine in the industry. The problem was to provide a continuous supply of timber and to see that we got the largest possible yield from our forest lands.

\section{Royal CoMmission-1945}

Pressure from many interested parties finally resulted in a Royal Commission being appointed to look into the situation. The late Chief Justice Sloan listened to thousands of pages of evidence and opinions and then produced his report in 1945 . When Mr. Sloan had finished the public hearings he found himself faced with the following facts:

1. Timber disposal by the government was mainly a liquidation policy.

2. The total forest land in the Province was 136 million acres-126.5 million acres owned by the Province and 9.5 million acres of the best forest land alienated.

As far back as 1904, the government of the day needed money and they raised it by selling Timber Leases and Licences. The interior licences were in general allowed to revert to the Crown over the years but on the coast, they remained alienated. Added to these was the timber acquired by large companies from the $\mathrm{E} \& \mathrm{~N}$ Railway land grant. This made up the bulk of the important alienations.

3. Provincial governments had never felt that they could support a sustained yield policy.

\footnotetext{
${ }^{1}$ District Forester, Vancouver Forest District, B.C. Department of Lands, Forests, and Water Resources, Vancouver, B.C.
} 
4. The companies did not own enough forest land to interest capital in the plant expansion needed for better utilization because they could not show how their lands could be properly managed to sustain the cuts required.

One of the first problems faced (by Sloan) was how to break down the 136 million acres of productive forest land into workable units, and the second, how to bring privately-held and controlled lands under sustained yield.

He reasoned that stability was a must, so he recommended two steps:

1. Part of the Crown-owned forest land should be managed by the Forest Service for smaller operators. The sustained yield aspect would make financing easier for small operators and would smooth out many other problems which arise from a liquidation policy; also it would act as a balance for his second proposal.

2. The rest should be under Tree Farm Licences. These were to be cooperatively-managed areas. The management and problems were to be shared by the licensee and the government.

The companies were to supply some forest lands, manufacturing plants, logging equipment and business ability. The government had to add enough forest land to ensure sustained yield at a suitable annual cut, and had to see that the public interest was protected.

As in all similar endeavours you can get an argument in British Columbia by people trying to decide whether the recommendations were good, bad or indifferent but it is always well to remember that after listening to millions of words of evidence Sloan had to make a suitable compromise recommendation, and also to remember that the conditions he found were in part the result of a decision made forty years before.

These two recommendations will be considered separately in greater detail. Also, growing out of these two main recommendations are three others, namely, Farm Woodlots, Pulp Harvesting areas and Certified Tree Farms.

\section{Tree Farm Licences}

Although the government professed sympathy with the foresters in British Columbia, it did not show it in any tangible form. Appropriations for the Forest Service were inadequate. From the evidence Sloan gathered he knew we needed forest management. Dr. Orchard (then Deputy Minister and Chief Forester) had arrived at the conclusion that a sound forest management partnership could exist between private enterprise and the government. This plan served several purposes:

1. All forest land in the licence, private and government, would be managed as a unit.

2. The companies would be allowed a share of their forestry expenses.

3 . The people would gain by intensive management and new manufacturing plants.

4. The companies would obtain relief from heavy annual taxes and carrying charges that are not related to the ability of the land to produce.

5. The companies would have the privilege of managing the licence. 
6. The companies would benefit by the possibility of long-term planning as a result of assured long-term occupancy. The original licences were perpetual-later ones were for 21 years.

7. There would be greater possibility for the companies to borrow money for expansion.

8. Timber lands in private hands from which timber was exportable would again come under Provincial control.

The Licence Document

When a person or company applied for a Tree Farm Licence, the Forest Service and the applicant met to discuss the application.

If the preliminary negotiations between an applicant and the government were satisfactory, a licence document was drawn up. The documents differed depending on conditions, but in general covered certain items such as:

1. description of the area involved,

2. purpose of the licence-usually for the maintenance of a supply of raw material for a plant,

3. the annual harvest intended,

4. provision for withdrawal of lands,

5. legal requirements of various kinds, and

6. management plans.

\section{Management Plans}

One of the most important points was the agreement to produce a suitable working plan. The working plans are for varying numbers of years. The first ones were for short terms. The term was just long enough for the companies to gather basic inventory information so that the second working plans could be more realistic depending on the actual conditions as discovered during the period of the first plan.

The working plan contained the usual items: 1 . summary of planned performance; 2. summary of basic facts, and 3. management plan including: objectives, cutting method, allowable annual cut, development of forest, reforestation, access, protection, provision for review, research, and annual report.

Working plans for the whole licence were submitted by the company forester. If acceptable, the document was signed. The first working plans were sketchy. This was understandable and was accepted by the government because no one had an intimate knowledge of the area. The Forest Service in many cases had the best information and shared it freely. Although the first plans were sketchy they contained commitments for improved inventory, cutting plans, protection plans against fire, insects and disease, reforestation and logging plans.

One of the most important items was to undertake a proper inventory to a given standard. We expected this to be done during the period of the first plan and it had to be for the whole area.

The second most important item was an immediate and substantial start on a protection plan for the whole area.

The cutting system had to be devised so that the areas logged regenerated naturally in five years or the areas had to be planted. 
Over a five-year period the cut had to be within 10 per cent of the estimated allowable cut.

\section{Cutting Permits}

Once the working plan is prepared, the actual cutting is covered by a cutting permit. The cutting permit may be for several years' cut depending on the working plan. The cutting permits are laid out to accomplish all the ideas set forth in the working plan, and we hope that as the licence develops and the working plans become more realistic (by this I mean based on better knowledge of the Tree Farm Licence) then the cutting permits and permit procedure will become more simplified.

The cutting permit is the result of intensive planning in a given area. For instance, if the basic plan is clear cut, salvage or burn, and plant, then the cutting permit areas are laid out with this plan in mind, so that the plan can be carried out in the best and cheapest way.

Results

On January 1, 1962, there were 39 Licences covering 7 million productive acres with an allowable cut of 324 million cubic feet. The smallest is 4,353 acres with a cut of $208 \mathrm{M}$ cubic feet and the largest, 1,961,399 acres with a cut of $22,000 \mathrm{M}$ cubic feet. Others of smaller areas have larger cuts.

\section{Introduction}

Public Working Circles

The second recommendation arising from the Royal Commission on Forestry was to manage the remaining forest lands as Public Working Circles. This is actually not a new concept of course. The Public Working Circles are just an extension and continuation of the Dominion Forest Reserves, first established in the railway belt. In 1911, seven Forest Reserves were established. These were added to by the Dominion later. The first Provincial Forest Reserve was established in 1914, in the Elk River Valley on provincial forest land. In 1930, the railway belt was reconveyed to the Province and all the forest reserves came under provincial jurisdiction.

In this period, neither public opinion nor public funds would permit proper forest management by the Forest Service to any great extent. However, the Forest Service never stopped trying and gradually some sustained yield concepts were introduced. This continued until 1945, rather slowly, and then Sloan's recommendation gave the plan great impetus.

Let us see what has taken place since 1945 , by way of ensuring a continuous timber supply by Public Working Circles.

The Public Working Circle as we know it does not fit the text book concept of a managed unit.

Our old Timber Sale policy was more or less a liquidation policy with as many forestry principles and safeguards inserted by the Forest Service as possible without upsetting the industry and politicians unduly.

To change over to the new policy, we first very roughly set up management units. The units are not all they might be, but we had to incorporate the administrative areas and our established Forest Service into the new concept. We could not start from scratch and do everything by the book. 
The units were organized as follows:

1. The responsible Forest Officer proposed an area for sustained yield management.

2. The approximate areas of forest land and cover were estimated.

3. A preliminary allowable cut based on available inventory information was calculated.

4. We determined who would be considered established operators and the relationship between allowable cut and actual cut from previous years' experience.

5. We made the relationship workable by adding areas or reducing the volume sold to each operator.

6. Having established a list of eligible operators and the assigned cut of each, the unit was approved and became an operating Public Working Circle.

\section{The Licensee Priority System in Public Working Circles}

Determining who had the right to apply for timber in the Circles was the real problem. On one hand we have a group of loggers who were cutting timber under timber sale on Crown lands. Naturally, since they used to have the choice of what they wanted put up for sale, they were all operating in the most accessible areas and the best timber. On the other hand, we proposed to limit their cut, if necessary. We must do this without creating too many problems so we first had to settle who, and how much. The present system is the result of experience and correcting the inequalities in preliminary methods.

An established licensee is any person who has held within a managed unit a Crown Timber Sale, in his own name, from which there has been a recorded production within the past three years, or any party who currently holds a Crown Timber Sale within a managed unit. The licensee is said to have an assigned commitment. The assigned commitment is the percentage of the allowable cut set aside for his use.

The logger is not entirely restricted to cut a given quantity each year-he may $\log$ faster or slower but he is only allowed a new sale to replace what he has cut and this amount is equal to his quota. If the has a tenyear sale and cuts it in eight years he must reduce his cut to zero for two years.

The sales are auctioned and anyone can bid. However, if the unit is fully committed, the applicant can elect sealed tender bidding and he can meet the highest bid after tenders are opened.

Sales can be applied for in advance to build roads.

\section{Management Plans}

For many years the two main purposes of the Forest Service were to sell Crown timber by timber sale to the highest bidder and to protect the forests from fire. The Forest Service was organized to carry out these two duties in the best possible way. Our present ranger district organization resulted. This organization does not, in all cases, fit the new Public Working Circle concept. Furthermore, we are still allowing a timber sale applicant (quota holder) to tell us where he wants his next timber sale. 
Because of these difficulties and limitations of time and staff we do not have a complete working plan for each area. The most important item missing from our plans is a proper cutting sequence in our old growth timber based on pathological and economic considerations. We have a good protection plan for each area. All aspects of protection have been considered and within the limits of the funds available, protection from fire, insects, and disease is well in hand. For instance, we spend about $\$ 60,000$ per year on snag falling in the Vancouver district. The average cost is about $\$ 8.50$ per acre treated. Reforestation is carried out on some areas. Since 1930 the Forest Service has planted $149,000,000$ trees on 226,000 acres.

We have limited the cut on a sustained yield basis. We reserve the privilege of disallowing sale applications for silvicultural reasons, protection reasons, and age of stand. We have tried to guide the cutting sequence by building access roads. To date, 529 miles of access roads have been built to open up timber stands. Logging plans are a requirement on all large timber sales. Stand treatment designed to stimulate growth, natural regeneration, or both, is being stepped up. In 1961, 133,000 acres were treated by Forest Service crews. Tree marking, scarification, slash burning, snag falling and evaluation studies are all part of the work.

\section{Results}

On January 1, 1962, there were 78 Public Working Circles in the Province containing 46 million accessible productive acres ( 84 million acres in total) and producing 515 million cubic feet annually.

\section{Introduction}

FARM WOODLOTS

In 1948, the Forest Act was amended to allow another type of managed forest unit. Bona fide farmers were permitted to obtain Crown land for the purpose of managing it together with any forest land they might own themselves. The cut cannot exceed $10 \mathrm{M}$ c.f. of wood products per year from the total area both Crown and private; area also is limited.

Selection of Crown Land and Management Plan

It is the farmer's responsibility to locate the Crown lands he wishes to include in his Farm Woodlot. The Woodlot should be within 20 miles of the licensee's farm by accessible road. It should contain a range of age classes and not too much overmature timber. Enough merchantable trees must be present to provide salable annual or periodic cut on a sustained yield basis. The ground must also be suitable for a small tractor, or horses.

The Forest Act requires that a plan of management for a proposed woodlot shall be drawn up and approved by the Chief Forester before a licence may be awarded.

The plan is drawn up by the Forest Service without cost to the farmer and forms part of his Farm Woodlot contract. The plan outlines how the woodlot should be managed during the first ten years following award of the licence and proposes some general principles to be followed in the long-term management of the area.

\section{The Farm Woodlot Contract}

The farmer must put up a One Hundred Dollar deposit at the time the agreement is signed. The contract includes the following general principles: 
1. The licence shall remain in effect during the lifetime of the farmer.

2. It must include his own forest lands.

3. Unstocked land in the licence must be stocked within five years with salable species.

4. The farmer must cut no less than 50 per cent and no more than 120 per cent of the accumulative 5-year cut over a 5-year period.

5. Periodic management plans must be approved by the Chief Forester.

6. The farmer will not cut unless he has an approved cutting permit.

7. The farmer will pay stumpage for any wood removed from Crown lands in the Woodlot.

8. He will pay for all unnecessary damage caused to the timber during logging or at any other time.

9. The licence may be terminated at any time by mutual consent of either contracting parties.

The first Farm Woodlot Licence was awarded in March, 1951, and up until the end of 1961, over 50 licences had been granted.

Woodlots vary in size due mainly to the varying capacity of the land to grow timber (smallest-69 acres-largest-445 acres). Most Woodlots are composed of 25 per cent land owned by the farmers and 75 per cent Crown land.

These licences have been issued in every part of the Province, the first being issued near Nanaimo.

Results

The total allowable cut of the 50 licences is approximately $320 \mathrm{M}$ c.f. The acreage involved is 12,000 acres.

\section{Certified Tree Farm}

Still another form of forest management is the Certified Tree Farm.

In 1951, amendments to the Taxation Act were introduced to encourage the practice of sustained yield on privately-owned forest lands. Forest land owners who make application and who demonstrate their willingness to practise the basic principles of forest management, will receive a tree farm classification for valuation and annual property tax purposes. The basic difference is that the annual valuation of normal timberland and wild land is based on the standing inventory of trees and site characteristics, whereas tree farm land is valued in accordance with the annual or periodic crop obtainable from the growth capacity. Moreover, the general taxation rate is 1 per cent per annum of the assessed value on tree farm land, in place of the $1 \frac{1}{2}$ per cent on timberland and 3 per cent on wild land. In return for this tax relief the forest owner must balance bis cut against the ability of the land to produce. He must keep his land fully stocked and he must offer protection against fire, insects, diseases, and grazing damage. The practices relating to the sustained yield management of the Tree Farm are outlined in a Management Working Plan, to be approved by the Forest Service.

At the end of December, 1961, there were 35 Certified Tree Farms in British Columbia containing a total productive area of 829,679 acres and sustaining an annual production of 33.3 million cubic feet and 386,740 Christmas Trees ( 3 of the Tree Farms are certified for production of Christmas trees only). 
It should be noted that much of the land included in Certified Tree Farms is also included in other types of managed areas. Excluding those Tree Farms which are also parts of Tree Farm Licences, we had 22 units consisting of 545,000 productive acres with an annual cut of $22,000 \mathrm{M}$ c.f.

\section{Pulp Harvesting Areas}

We have one more management concept in British Columbia. In the interior we have mainly a sawmill economy. To get the best management it was agreed that pulp mills were required. The pulp harvesting area was designed to make full use of the wood in a combined pulp and sawmill economy without disturbing the present sawmill economy, but in reality aiding it.

The basic idea is to allow the sawmills to remove the timber suitable for lumber and the pulp harvesting area licensee salvages and removes the logs suitable for pulp.

The pulp harvesting licensee would use:

1. wood presently left in the course of harvesting sawlogs.

2. stands on low sites where stands would not develop into sawlog size within a reasonable growing period.

3. stands which are overmature or decadent and not suitable for sawlogs due to size, defect or species.

It is immediately apparent that there are many possible areas of conflict when we attempt to obtain integrated use of the wood available and still allow each type of operator to retain independent control of part of the supply. We do not underrate the possible conflict but we do know that there is always a solution if both parties to a dispute are determined to reach agreement.

The forest management aspects of this type of managed area will be included in the timber sale contracts which will be issued to legalize the harvesting under the Pulp Harvesting Licence.

At this time a Pulp Harvesting Area in the Prince George District has been tentatively approved. The Prince George area involves a total acreage of about 8 million acres of forest land. A large percentage of the timber on the area has already been dedicated to the sawmill economy but it is estimated that there will be ample material to keep a 500-ton-per-day pulp mill supplied with the objective of double that tonnage at a later date. A second Pulp Harvesting Area near Kamloops also has been tentatively approved. The Kamloops area involves an acreage of 7,500,000 acres. A 200ton-per-day pulp mill is proposed with the ultimate intention of increasing this to 800 tons.

\section{Conclusions}

If you add up all the areas under the various types of managed units you will find that we have 53.7 million productive acres producing 860,000 $\mathrm{M}$ cubic feet under some type of management. This has been accomplished 
in 17 years without disrupting the economy in any way. In this last few years five new pulp mills have been built, six others have been expanded and at least five more are projected. Most of the people in British Columbia connected with the forest industry are satisfied that we would never have had this expansion without forest management. We perhaps might have had similar expansion if we had sold all our forest lands but the public would not have accepted that. Most of the Tree Farm Licences have submitted their second working plans and some of them the third. Only one has been threatened with cancellation so they have a good record.

The Public Working Circles are working well although we have a long way to go. Pulp Harvesting Areas have still to prove themselves. Farm Woodlots and Taxation Tree Farms are working well. I can say without any qualms that forest management in British Columbia is a success and can easily produce a continuous supply of timber for our great industry which accounts for about 50 per cent of our economy. 